\title{
Development and Usability Assessment of Classroom Surveillance System for Campus Security and Productivity
}

\author{
Esselyn S. Recososa \\ Jose Rizal Memorial State University
}

\begin{abstract}
Classroom Surveillance System is an excellent system for higher learning institutions to ensure the security of students, faculty, office personnel, and its physical facilities. This study aimed to develop a classroom surveillance system for campus security and productivity. The study utilized developmental research. There were four Deans, 24 IT professionals, and 24 students utilized as respondents of the study. The instrument used in the study included the Deans' monitoring scheme of teaching/non-teaching personnel, school facilities, and student's assessment on the surveillance functionality, reliability, usability, efficiency, maintainability, and accuracy of the newly developed and designed classroom surveillance system. The statistical tools used were the frequency count, ranking, and weighted mean. The study revealed that the developed Classroom Surveillance System was very much functional, very much reliable, very much usable, very much efficient, very much maintainable, and very much accurate. The university administration should adopt the Classroom Surveillance System to provide excellent surveillance and monitoring of teaching personnel, non-teaching personnel, classroom facilities, and students of the University. Hence, the university should shift from utilizing the traditional surveillance system into a technologically oriented surveillance system.
\end{abstract}

Keywords: Classroom Surveillance System, System Development, Security, Innovation

\section{Introduction}

As technology continues to advance rapidly, computer technology is making breakthroughs all over the globe. Lukas et al (2016) averred that computers are built into watches, automobiles, and numerous household appliances, practically, becoming omnipresent in all facets of society. Unlike in the past years, possession of computers was deemed luxurious, today it is as a vital necessity playing a very significant role in the academe and education. Its widespread adoption led to the increasing new development of technology. One of this is the recently partnership of computer technology and television. It is a breakthrough that changed the world. Television being the window to the world, through which people are entertained and informed. It went through a tremendous variety of programming for the consumption of the consumer audience. The first of its development is the ClosedCircuit Television (CCTV) which has long been used as a powerful surveillance tool for fighting crimes (Robin et al, 2020). Along this context, Stainer, et al, (2021) pointed out that CCTV is the finest weapon in security armory. As a result, advances in video security and surveillance technology were made creating and developing automatic surveillance systems to expand CCTV cameras' effectiveness. From the functionalist perspective there is an increasing reliance of society to technology (Ceccato, et al, 2021, Cho \& Park, 2017, Effah, et al, 2020, Hodgetts, et al, 2017, Surantha \& Wicaksono, 2018).

Technological advancements in surveillance systems at significant scale were carried out in many countries to capture day-to-day activities, detect and track objects, and in higher levels to analyze targets' behavior (Underwood, et al, 2020, SHepeley et al, 2020). In fact, surveillance systems also do other things like monitoring traffic and helping traffic officers resolve traffic accidents by studying the captured screen shots. Evidently, there is a widespread use of the technology with its application seen in almost all fields of life. 
In schools, however, surveillance system established in class does not only address education per se but also as part of providing the safety to the students (Zhou, Yu \& Shi, 2020). It cannot be overemphasized that schools lay the foundation of a child's future and hence different students from different walks of life come to schools to gain the knowledge. Irrespective of political affiliation, economic status, religion, and culture, they all attend the classes under one roof. Therefore, just like elders, the students are most likely the ones to get into trouble and fights among themselves. The recent spate of violence and illegal incidence, such as shootout by mentally disturbed persons, terroristic attack, drug peddling, vandalism, occurring in schools are at alarming level resulted to the growing efforts to provide better equipment that can anticipate the safety of the school clients. The school administration today seeks the professional help in order to curb threats against persons, facilities and the like. Along this context, the most crucial method recommended to make schools a safer place for education is to cover the premises and students through a surveillance security systems (Birnhack \& Perry-Hazan, 2020 , Wang, 2020, Zhou, et al, 2020), which were uncommon before.

Imbued with the benefits that the surveillance system provides, Socha \& Kogut (2020) enumerated the following: it helps prevent petty unsavory incidents in schools; it prevents vandalism; it keeps the area secure and can even help prevent fire; it helps monitor teacher's performance and it curbs students' behaviours. Indeed surveillance system is viewed to improve security management of the school. It is believed that Jose Rizal Memorial State University, Dipolog Campus, needs to provide classroom surveillance system in the campus considering its growing population. The campus is catering students from different walks of life as it is in the heart of a busy city. Hence, the classroom surveillance system was designed to provide the University a research-based output and a view of the positive contributions it can offer to students, teaching and non-teaching staff, the parents and the University as a whole.

Automatic surveillance systems monitor the displays and alert the security controller when there is an extraordinary and unusual situation. In other words, they provide automatic real time interpretation of scenes covered. Kennedy (2017) asserted that the main goal of automatic surveillance systems is to obtain a description of what is happening in a monitored area and then to take appropriate action based on that interpretation. Automatic systems are inevitable and the task is impossible to be done manually. Fiher et al (2019) averred that proactive surveillance seems impossible since there are too many cameras and too few pairs of eyes to keep track of them. Further, the task is difficult or unethical to be done by human operators like detecting unattended bag in a university campus (Perry-Hazan \& Birnhack, 2019). Cho, Mansfield, \& Claughton (2020) added, that automation can extend human capability since response time would increase with the aid of an automatic surveillance systems.

Despite the recent improvements in developing intelligent surveillance systems, their effectiveness and efficiency are still not sufficient to meet real-time surveillance requirements. Jansen et al (2017) pointed out that, apart from effectiveness of automatic surveillance system, there are factors which are responsible for acceptance of such automated systems by operators which are classified, namely: the extent to which organizations encourage the use of automated systems, the extent to which reliance on automated decision aids is acceptable, and the extent to which automation is seen as an expert and one that is perceived to yield more accurate and reliance outcome than people's own judgment. 


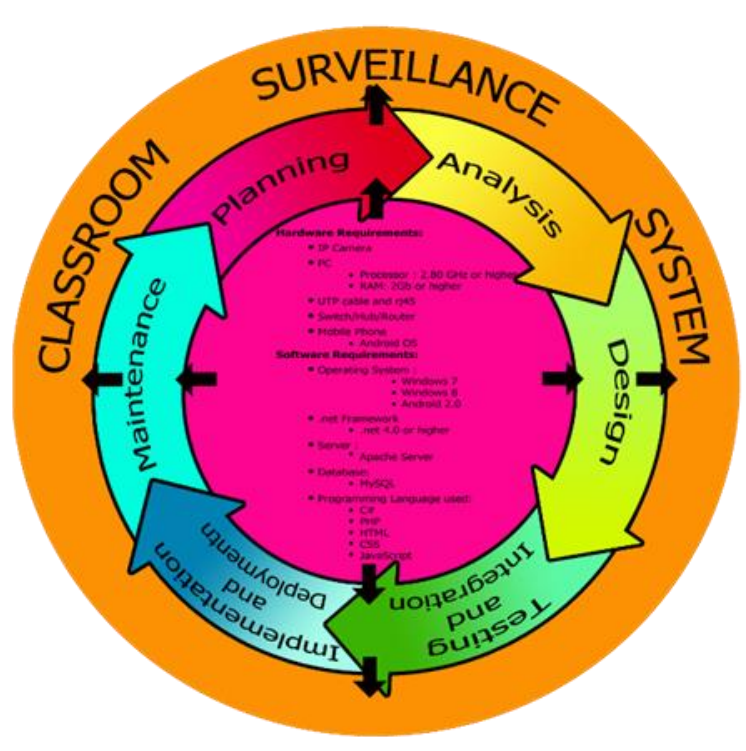

Figure 1. Schema of the System

In this project, classroom surveillance system is proposed in order to provide users with information termed as confidence information. This information is the extent to which the system is certain about its choice. Classroom surveillance system is prototyped which tests varying levels of functionality, reliability, usability, efficiency, maintainability, and accuracy. The schema of the study is presented in Figure 1 which involves three (3) important stages, namely: requirements in putting up a Classroom Surveillance System, system development life cycle, and the output of the system design. The innermost circle contains hardware and software components of the system, The hardware requirement includes namely computers, IP Camera , UTP cable and rj45, router, mobile phone while the software requirements include Operating System, Apache Server, MySQL for the Database, Programming Language used are C\#, PHP, HTML, CSS and JavaScript.

The middle circle contains the system development life cycle, namely: planning phase, analysis phase, design phase, testing and integration, implementation and deployment, and maintenance phase. The arrow denotes the sequence of processes followed in the development of the system.
Planning Phase. This involves data collection which generates or brings together information that has been systematically observed, recorded, organized, categorized, or defined in such a way that logical processing and inferences may occur. This is a system development life cycle which involves the process of extracting information from the users of the same project through documents and reports. Al-Qawasmi (2018) asserted that this phase is the most crucial step in creating a successful system. He emphasized that it is during this phase in which one has to decide exactly what he wants to do; defines the problems, the objectives and the resources such as personnel and costs; knows the ability of proposing alternative solutions after meeting with clients, suppliers, consultants and employees; and learns how to make the product better than the competitors.

Analysis Phase. This includes the process of defining and describing the necessary requirements needed for the formation of the proposed project are made. According toWagner (2017), requirements analysis is also called requirements engineering. It is the process of determining user expectations for a new or modified product. These features, called requirements must be quantifiable, relevant and detailed. In software engineering, such requirements are often called functional specifications. Wagner (2017) asserted further that analysis phase is an important aspect of project management which involves the following stages, namely: frequent communication with system users to determine specific feature expectations, resolution of conflict or ambiguity in requirements as demanded by the various users or groups of users, avoidance of feature creep and documentation of all aspects of the project development process from start to finish. Energy should be directed towards ensuring that the final system or product conforms to client needs rather than attempting to mold user expectations to fit the requirements. In general, analysis phase is a team effort that demands a combination of hardware, software and human factors engineering expertise 
as well as skills in dealing with people.

Moreover, Al-Qawasmi (2018) pointed out that the end-user's requirements should be determined and properly documented, what their expectations are for the system, and how it will perform. A feasibility study is suggested to be made for the project as well, involving determining whether it is organizationally, economically, socially, technologically feasible. It is very important to maintain strong communication level with the clients to make sure of a clear vision of the finished product and its function.

Designing Phase. This is the third process where the drawing up plans or layouts for the proposed project takes place. This involves the preparation of the abstract representation of the project, the students' entrance security system. The architecture of the project is concerned with making sure that it meets the requirements of the end-users, as well as ensuring that the future requirements of the project can be addressed. This step also addresses interfaces of the software system as well as the underlying hardware or the host operating system. Al-Qawasmi (2018) stressed further that this phase comes after a good understanding of customer's requirements and defines the elements of a system, the components, the security level, modules, architecture and the different interfaces and type of data that goes through the system. In general, this phase determines how the system will look like and how it will function, and then a detailed and expanded system design is produced, and it will meet all functional and technical requirements logically and physically.

Testing and Integration. This refers to a program, procedure, or process to obtain, verify, or provide data for determining the degree to which a system (or subsystem) meets, exceeds, or fails to meet its stated requirements. This also obtains raw data, measures specific, individual performance factors, and determines if the project is resource intensive. Al-Qawasmi (2018) disclosed further that testing is becoming more and more important to ensure customer's satisfaction. It can be performed by real users, or by a team of specialized personnel. Moreover, it can also be systematic and automated to ensure that the actual outcomes are compared and equal to the predicted and desired outcomes. Integration, on the other hand, is an evaluation phase which delves into reviewing, analyzing, and assessing data obtained from testing to project system performance under operational conditions. Evaluation produces analyzed information from test data, modeling and simulation, or other sources. It also draws conclusions by looking at how the factors interact. Moreover, it determines if the project is intellectually intensive. The researcher and respondents of the study conducted testing and evaluated on the levels of functionality, reliability, usability, efficiency, maintainability, and accuracy of the system.

Implementation and Deployment. During the process, the system is installed and made operational in the production environment after the system and users' acceptance testing. Activities in this phase include efforts required for implementation including notification to end users, execution of training, data entry or conversion, and system monitoring. The process continues until the production system is operating in accordance with the defined requirements and planning for sustainment. Al-Qawasmi (2018) affirmed that this phase comes after a complete understanding of system requirements and specifications. This pertains also to the actual construction process after having a complete and illustrated design for the requested system. In this phase, the system is ready to be deployed and installed in the customer's premises. The system is also ready for running, live and productive. There is a need for the end users to make sure that they know how to use the system and to get familiar with it which takes a long time and may depend on the complexity of the system and the solution it presents.

Maintenance. In this process, periodic maintenance for the system is carried out to make 
sure that the system would not become obsolete. This includes replacing the old hardware and continuously evaluating system's performance. It also includes providing latest updates for certain components to make sure it meets the right standards and the latest technologies to face current security threats.

Finally, the outermost circle reflects the output of the study which is the Classroom Surveillance System for Jose Rizal Memorial State University, Dipolog Campus. The system provides great benefit for the institution by serving as a security gadget that monitors the physical facilities, personnel, and students. The project ensures that security and monitoring of all concern is made easy but properly observed. Moreover untoward incidents in the classroom are prevented or minimized.

\section{Objectives of the Study}

This study aimed to develop a classroom surveillance system for Jose Rizal Memorial State University (JRMSU), Dipolog Campus, Philippines. Specifically, this study sought answers to the following questions: (1) What classroom surveillance is existing for monitoring: teaching personnel; non-teaching personnel; classroom facilities; and students. (2) What is the extent of effectiveness of the existing classroom surveillance", (3) What new classroom surveillance system could be adopted? (4) What status could be expected from the new adopted classroom surveillance system along: functionality; reliability; usability; efficiency; maintainability; and accuracy. What technological features could be developed for new classroom surveillance system?

\section{Research Methodology}

\section{Method Used}

The study utilized the developmental research method. It is a method that involves a systematic study of designing, developing, and evaluating computer programs, processes, and products to meet the criteria of internal consistency and effectiveness.
Developmental research is particularly important in the field of information and communication technology as the case undertaken. In this research the product development process is analyzed and described, and the final product is tested and evaluated.

\section{Research Environment}

The Jose Rizal Memorial State University (JRMSU), the Premier University in Zamboanga del Norte, by virtue of Republic Act 9852 is a state university in the country. It is mandated to provide higher professional, technical, and special instructions for special purposes and promote research and extension services, advanced studies, and progressive leadership in education, agriculture, arts and sciences, engineering, and other fields. The JRMSU system has six (6) campuses with the main campus situated in Dapitan City. Other campuses are located in Siocon, Tampilisan, Sibuco, Katipunan, and Dipolog City all in the Province of Zamboanga del Norte.JRMSU Dipolog Campus is situated in Dipolog City, the gateway to Mindanao and the capital city of Zamboanga del Norte. Academic freedom, an ingredient of a progressing institution is felt within the campus after a takeover on December 15, 2009 of Zamboanga del Norte School of Arts and Trades. That is how she was fondly called is now a campus of JRMSU. Still standing proud on a nearly 3-hectare site in Turno, Dipolog City and along the national highway, just about a mile away from the very heart of the city, the new JRMSU is continuously heading its way to progress with Dr. Edgar S. Balbuena as the President. The growing status of the University in terms of human resources, physical facilities, financial resources, instructional material resources, and enrollment, the university is now experiencing intimidation by intruders and criminals. The safety of its clients and personnel including the protection of its physical facilities and resources cannot be compromised instead challenged the concern of school officials to address it. The recent developments in the school premises indeed 
prompted the researcher to come up with safety, prevention and protection measures for the University. The effort is at the same time a response to the call of the Management Association of Security and School Officials, Inc (MASSO) for schools and universities to put up CCTV cameras in strategic areas (Corpus, 2011). Coupled with observations and practices in the security measures of the University, the researcher develops the system for purposes of improving to a higher level the university's safety measure, prevention, and protection.

\section{Project Design}

Figure 2 shows the project design of the Classroom Surveillance System. Surveillance camera 1 and surveillance camera 2 are the major components of the classroom surveillance system which used IP cameras with panning left to right capability and tilting capability up to bottom movement. The surveillance cameras also used infrared technology for night vision capability, and it has a voice capability to pick up sounds in the classroom where it is installed. The client PC represents the Administrator Control Panel, Dean Control Panel and the guard control panel. All of the client PC's are wired to the router preferably a Linksys type from CISCO which has all the capability of typical commercial small router. The cabling used are UTP Ethernet cabling and also ideal to small and large campus size local network.
The router provides DHCP service for the client PC, other camera and mobile phones, but the web server has a static IP address which does not need DHCP service forms the router. It also provides and acts as a hub or switch for the client PC's and allows the mobile phones to gain access to the local and network to the system. The web server provides the HTTP service to all clients either PC or mobile phones. This means that the Classroom Surveillance System can be accessed through web browsers such as Google Chrome and Mozilla Firefox and other compatible browsers. This capability enables the users of the system to watch and view videos or captured video streams from their mobile phones all the way through Jose Rizal Memorial State University.

The web server also hosted the MySQL database which holds all the data configuration of the system. It also holds all the saved captured videos from the camera. The web server is the most important part of the system, without it the system will not run, so it must be placed in a secure and safe place where only the network administrator, the authorized personnel has the access. The WAMP application is installed in the web server for the deployment of the system page or site. The said application has all the necessary servers like Apache, MySQL and PHP in order for the Classroom Surveillance System to run properly. 


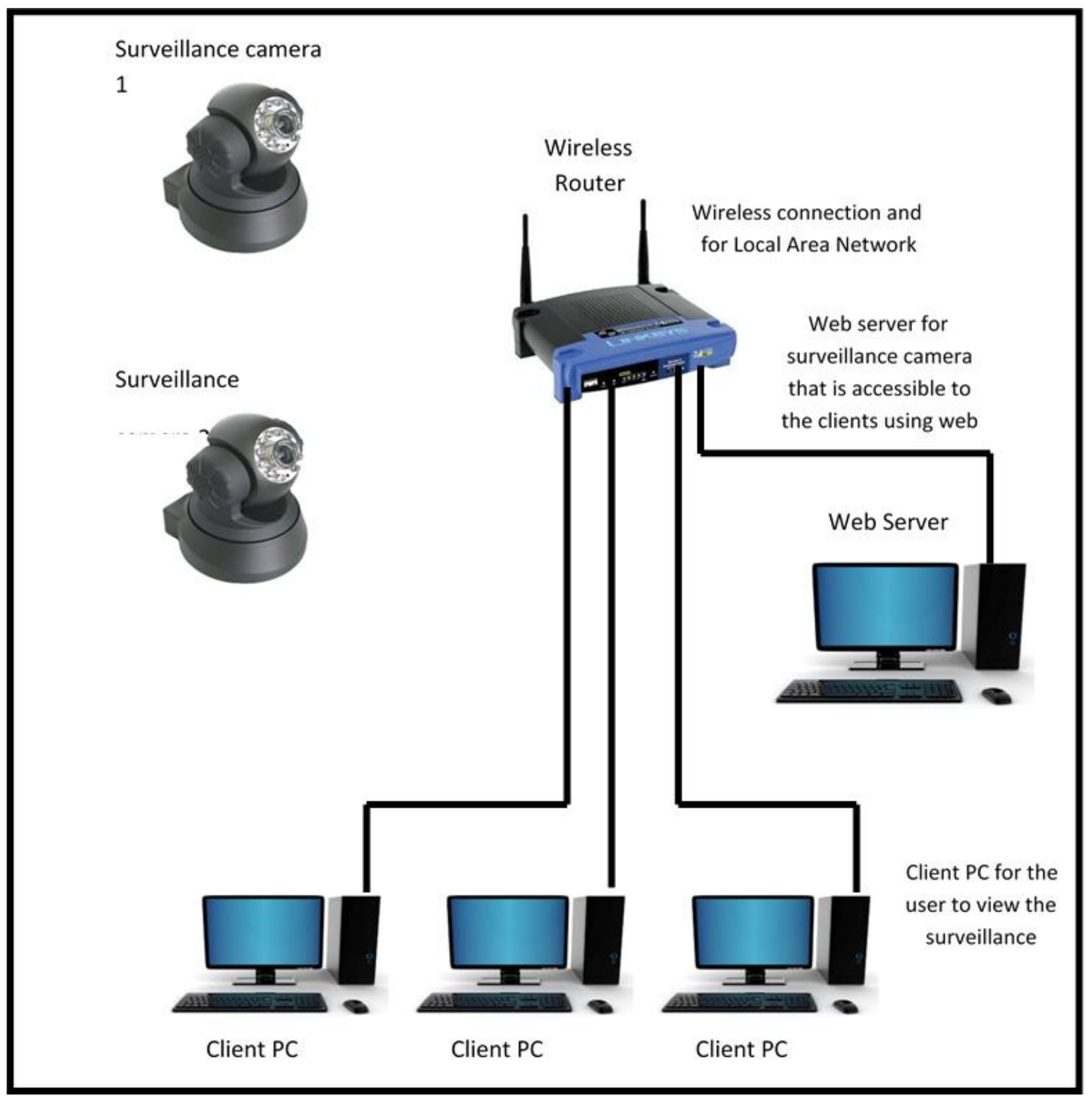

Figure 2 Project Design of the Classroom Surveillance System

\section{Respondents of the Study}

The study utilized fifty-two respondents, composed of the Deans of the different colleges of the Dipolog Campus, IT students of the main campus and IT professors. They provided the information regarding the existing surveillance used and practiced in the campus. The degree of effectiveness in the implementation of traditional surveillance was evaluated. To check the status of the new classroom surveillance system along functionality, reliability, usability, efficiency, maintainability, and accuracy, the respondents were classified into four (4) groups of evaluators, namely: IT students of the Main Campus, IT professionals of the Dipolog Campus, IT Professionals of the Main Campus, and IT professionals of the selected private institutions in Dipolog City. No sampling technique was used in the selection of the IT professionals since all IT professionals from the Main Campus, Dipolog Campus, and private institutions in Dipolog City were utilized as respondents. However, a purposive sampling technique was employed in the selection of 
the student - respondents of the study. The number of students equated to the number of IT professionals utilized to offset the strength of IT professionals in the decision making. These were third year and fourth year IT students of the Jose Rizal Memorial State University, Main Campus, Dapitan City considering that Dipolog Campus is not offering an IT course.There were four Deans, twenty four IT students from the Main Campus; ten IT professionals of the Main Campus; two IT professionals of Dipolog Campus and twelve IT professionals from Private Institutions in Zamboanga del Norte.

\section{Research Instrument}

The instrument which was utilized in gathering data in the study composed of two parts. The first part was researcher made. It dealt with the monitoring scheme of teaching/non-teaching personnel, school facilities, and students for the Deans to assess the surveillance used and practiced in the campus. The purpose of the questionnaire was to determine the extent of effectiveness in the implementation of the traditional surveillance system in the campus. The second part was patterned after the International Standard Organization (ISO) /IEC 9126 standard quality model which determined the functionality, reliability, usability, efficiency, maintainability, and accuracy of the newly developed and designed classroom surveillance system.

\section{Validation of the Instrument}

The first part of the questionnaire was referred to the adviser to pass judgment on the content, appropriateness and suitability of the instrument. With the adviser's recommendation, the instrument was subjected to a reliability test. Eight (8)Deans of the Main Campus not the respondents of the study but of similar characteristics with the respondents were used as pilot samples to test the reliability of the instrument. Cronbach's Alpha revealed an internal consistency reliability coefficient of 0.945 which indicated that the instrument was very highly reliable. Since the Cronbach's Alpha coefficient was reliable and very high, the research instrument was deemed valid and reliable. However, the evaluation sheet which determined the levels of functionality, reliability, utility, efficiency, maintainability, and accuracy of the newly developed and designed classroom surveillance system was not subjected to reliability testing.

\section{Scoring Procedure}

To draw out the responses as regard the traditional surveillance system used and practiced in the campus, the five-point Likert scale was primarily employed as follows:

\begin{tabular}{|c|l|l|l|l|l|}
\hline Scale & $\begin{array}{c}\text { Range of } \\
\text { Values }\end{array}$ & Effectiveness & Reliability & Usefulness & \multicolumn{1}{|c|}{ Efficiency } \\
\hline 5 & $4.21-5.00$ & $\begin{array}{l}\text { Very Much } \\
\text { Effective }\end{array}$ & $\begin{array}{l}\text { Very Much } \\
\text { Reliable }\end{array}$ & $\begin{array}{l}\text { Very Much } \\
\text { Useful }\end{array}$ & $\begin{array}{l}\text { Very Much } \\
\text { Efficient }\end{array}$ \\
\hline 4 & $3.41-4.20$ & Much Effective & Much Reliable & Much Useful & Much Efficient \\
\hline 3 & $2.61-3.40$ & Effective & Reliable & Useful & Efficient \\
\hline 2 & $1.81-2.60$ & Fairy Effective & Fairy Reliable & Fairy Useful & Fairy Efficient \\
\hline 1 & $1.00-1.80$ & Not Effective & Not Reliable & Not Useful & Not Efficient \\
\hline
\end{tabular}


University, Dapitan City seeking endorsement for the President of Jose Rizal Memorial State University System and Presidents of Private Institutions of Dipolog City to allow the administration of the instrument of the study. A letter of the researcher together with the endorsement letter from the Dean was sent to the President of Jose Rizal Memorial State University System and Presidents of Private Institutions of Dipolog City to gather data by administering the instrument of the study. Upon approval, the researcher personally administered the instrument to them. The evaluation rating sheets were then immediately retrieved. After the retrieval, the responses were tallied, computed, and interpreted employing the appropriate statistical tools.

\section{Statistical Tools}

This study used the following statistical tools such as frequency count to determine the traditional classroom surveillance existing in the campus in monitoring the teaching personnel, non-teaching personnel, classroom facilities, and students. Ranking was used to rank the traditional classroom surveillance existing in the campus in monitoring the teaching personnel, non-teaching personnel, classroom facilities, and students. Ranking was done based on the frequency where the highest is rank 1, next from the highest is rank 2, and the like. In the event of tie in frequencies, the rank of each of the items comprising the tie is the mean of their ranks. Weighted Mean was employed to find out the extent of effectiveness of the traditional surveillance system and the levels of functionality, reliability, utility, efficiency, maintainability, and accuracy of the newly developed and designed classroom surveillance system.

\section{Results and Discussion}

Research Problem 1. What classroom surveillance is existing for monitoring: teaching personnel; non-teaching personnel; classroom facilities; and students?

The result of the existing classroom surveillance scheme for monitoring faculty used by the Deans of the four colleges of Jose Rizal Memorial State University. The table shows that teaching personnel were monitored through daily time records, record/log book, and the performance appraisal system for instructors and professors. This is supported by an equal frequency of used and rank. On the other hand, non-teaching personnel were also monitored by the used of the daily time records, record/log book, and the performance evaluation report which obtained equal frequency of used and rank. Further, classroom facilities were evaluated on semestral basis while the students were often monitored by the teachers in their respective classes using the teachers' class records. Other teachers and professors also used index cards to reflect the attendance of the students. However, this excluded the records of misbehavior and other misdemeanors committed by the students.

Table 1 The Existing Classroom Surveillance of the Institution

\begin{tabular}{|l|c|c|}
\hline Teaching Personnel & Frequency & Rank \\
\hline Daily Time Records & 5 & 2 \\
\hline Record/Log Book & 5 & 2 \\
\hline Performance Appraisal System for Instructors and Professors & 5 & 2 \\
\hline Non-Teaching Personnel & Frequency & Rank \\
\hline Daily Time Record & 5 & 2 \\
\hline Record/Log Book & 5 & 2 \\
\hline Performance Evaluation Report & 5 & 2 \\
\hline
\end{tabular}




\begin{tabular}{|l|c|c|}
\hline Classroom Facilities & Frequency & Rank \\
\hline Semestral Inventory & 5 & 1 \\
\hline Students & Frequency & Rank \\
\hline Class Records of Teachers & 5 & 1.5 \\
\hline Index Cards & 5 & 1.5 \\
\hline
\end{tabular}

Research Problem No. 2. What is the extent of effectiveness of the existing classroom surveillance?

Table 2 presents the extent of effectiveness of the existing classroom surveillance system used by Deans in their respective colleges. By extent of effectiveness it refers to the degree to which objectives are achieved and the extent to which targeted problems are solved. It is determined without reference to costs and it means doing the right thing. It could be gleaned in the table that daily time records, record/log book, and performance appraisal system for instructors and professors were found "effective" as a monitoring scheme for the teaching personnel of the different colleges. It obtained a mean of 3.00. Similarly, daily time records, record/log book, and performance evaluation report were also found "effective" in monitoring the non-teaching personnel in the University. It obtained a mean of 3.00. As regard, semestral inventory of the classroom facilities of the different colleges was revealed "effective" as practiced by the Deans of colleges. It obtained a mean of 2.75. Further, class records of teachers as a monitoring instrument used to check the students were also found "effective". It registered an average weighted mean of 3.25. On the other hand, index cards were found only "fairly effective" to monitor the students. It obtained an average weighted mean of 2.25. In an interview conducted by the researcher, the instructors/professors indicated that index cards could hardly be kept as compared to class records. As per observation, however, the usage of index cards as monitoring device for student's attendance in classroom activities was only practiced by few instructors. Other instructors who have not at all utilized the index cards for monitoring explained that handling the cards is already very inconvenient for them to do. Moreover, these cards are different to keep intact, and are more prone to get easily lost. In totality, the extent of effectiveness of the existing classroom surveillance was "effective" as rated by the Deans. The overall mean obtained on the extent of effectiveness of the existing classroom surveillance is 2.88 . It is noteworthy to mention, that as far as monitoring is concerned, the raters found the class records to one effective as compared to other schemes like daily time record, log book, and performance appraisal system.

Table 2 The Extent of Effectiveness of the Existing Classroom Surveillance

\begin{tabular}{|c|c|c|c|c|c|c|}
\hline \multirow[t]{2}{*}{ Teaching Personnel } & \multicolumn{4}{|c|}{ Frequency } & \multirow{2}{*}{$\begin{array}{l}\text { Average } \\
\text { Weighted } \\
\text { Value }\end{array}$} & \multirow[b]{2}{*}{ Description } \\
\hline & 5 & 4 & 3 & 2 & & \\
\hline Daily Time Record & 1 & 2 & 1 & - & 3.00 & Effective \\
\hline Record/Log Book & 1 & 2 & 1 & - & 3.00 & Effective \\
\hline $\begin{array}{l}\text { Performance Appraisal } \\
\text { System for Instructors and } \\
\text { Professors }\end{array}$ & 1 & 2 & 1 & - & 3.00 & Effective \\
\hline
\end{tabular}




\begin{tabular}{|c|c|c|c|c|c|c|}
\hline \multicolumn{5}{|c|}{ Mean } & 3.00 & Effective \\
\hline \multirow[t]{2}{*}{ Non-Teaching Personnel } & \multicolumn{4}{|c|}{ Frequency } & \multirow{2}{*}{$\begin{array}{c}\text { Average } \\
\text { Weighted } \\
\text { Value }\end{array}$} & \multirow[b]{2}{*}{ Description } \\
\hline & 5 & 4 & 3 & 2 & & \\
\hline Daily Time Record & 1 & 2 & 1 & - & 3.00 & Effective \\
\hline Record/Log Book & 1 & 2 & 1 & - & 3.00 & Effective \\
\hline $\begin{array}{l}\text { Performance Evaluation } \\
\text { Report }\end{array}$ & 1 & 2 & 1 & - & 3.00 & Effective \\
\hline \multicolumn{5}{|l|}{ Mean } & 3.00 & Effective \\
\hline \multirow[t]{2}{*}{ Classroom Facilities } & \multicolumn{4}{|c|}{ Frequency } & Average & \multirow[b]{2}{*}{ Description } \\
\hline & 5 & 4 & 3 & 2 & $\begin{array}{c}\text { Weighted } \\
\text { Value }\end{array}$ & \\
\hline Semestral Inventory & - & - & 3 & 1 & 2.75 & Effective \\
\hline \multicolumn{5}{|c|}{ Mean } & 2.75 & \\
\hline \multirow[t]{2}{*}{ Students } & \multicolumn{4}{|c|}{ Frequency } & Average & \multirow[b]{2}{*}{ Description } \\
\hline & 5 & 4 & 3 & 2 & $\begin{array}{c}\text { Weighted } \\
\text { Value }\end{array}$ & \\
\hline Class Records of Teachers & - & 1 & 3 & - & 3.25 & Effective \\
\hline Index Cards & - & - & 1 & 3 & 2.25 & Fairly Effective \\
\hline \multicolumn{5}{|c|}{ Mean } & 2.75 & Effective \\
\hline \multicolumn{5}{|c|}{ Overall Mean } & 2.88 & Effective \\
\hline
\end{tabular}

\section{Research Problem No. 3. What new classroom surveillance system could be adopted?}

Security measures to monitor school activities of the teaching personnel, non-teaching personnel, students, and safety of classroom facilities could be strengthened by adopting surveillance technology called as Classroom Surveillance System. The system is a combination of the hardware and software technologies as like the surveillance IP camera, networking, and the internet. Using the existing outlets for internet connections in the school, IP cameras could simply be attached to these cable systems allowing to access images and videos from remote areas. Further, the system, like any other surveillance system, has the ability to capture images and videos that could be stored in a local hard drive or be transmitted to any other recipient via the internet connection.

The IP cameras of the classroom surveillance system are used to capture images and videos while the router is used to view and modify the IP routing table and to transfer images and videos. The DSL Modem is used to transmit images and videos over the internet. The server computer is used to handle all the controls over the camera. On the other hand, the client computer is used to view images and videos as duplicate copy from server computer and to conduct simultaneous viewing based on the server 
computer. There is also a remote computer used to view images and videos from server computer over an internet connection. In this system, the classroom surveillance system users store images and videos on local drive and send the same through email, schedule recording on a particular IP camera situated on a specific location or set a text message alarm when the camera senses a motion on a particular time, and move the head of the IP camera to any direction in order to focus a particular target location.

Research Problem No. 4. What status could be expected from the new adapted classroom surveillance system along: functionality, reliability; utility; efficiency; maintainability; and accuracy?

\section{Functionality}

In this study, functionality pertains to the sum or any aspect of what classroom surveillance system can do for a user. It is composed of ten descriptors which are measured by a five point scale ranging. There were two groups of respondents who evaluated the functionality of the system, namely: the IT professionals and the IT students. Table 3 shows that the system was "very much functional" along functionality. It obtained a mean of 4.34 as rated by the IT Professionals. IT student-raters, likewise, complemented that the system was "very much functional" with a mean of 4.40. It means that the system is very much serviceable for use as a security gadget and is very much convenient and capable to manage security measures in the University. It implies further that the system possesses the capability to capture images and transfer the images and videos over the internet.

Table 3 Software Quality Factor on Functionality

\begin{tabular}{|l|c|c|c|c|}
\hline \multicolumn{1}{|c|}{ Descriptors } & \multicolumn{2}{|c|}{ IT Professionals } & \multicolumn{2}{c|}{ IT Students } \\
\cline { 2 - 5 } & $\begin{array}{c}\text { Average } \\
\text { Weighted } \\
\text { Value }\end{array}$ & Description & $\begin{array}{c}\text { Average } \\
\text { Weighted } \\
\text { Value }\end{array}$ & Description \\
\hline $\begin{array}{l}\text { 1. Intended use of the } \\
\text { software }\end{array}$ & 4.17 & $\begin{array}{c}\text { Much } \\
\text { Functional }\end{array}$ & 4.25 & Very Much Functional \\
\hline $\begin{array}{l}\text { 2. Data manipulation } \\
\text { needs }\end{array}$ & 4.13 & $\begin{array}{c}\text { Much } \\
\text { Functional }\end{array}$ & 4.17 & Much Functional \\
\hline $\begin{array}{l}\text { 3. Compliance of end-user } \\
\text { 4. Security of system data }\end{array}$ & 4.25 & $\begin{array}{l}\text { Very Much } \\
\text { Functional }\end{array}$ & 4.29 & Very Much Functional \\
\hline $\begin{array}{l}\text { 5. Compatibility of other } \\
\text { System }\end{array}$ & 4.33 & $\begin{array}{l}\text { Very Much } \\
\text { Functional }\end{array}$ & 4.50 & Very Much Functional \\
\hline $\begin{array}{l}\text { 6. Speed in data } \\
\text { processing }\end{array}$ & 4.08 & $\begin{array}{c}\text { Much } \\
\text { Functional }\end{array}$ & 4.46 & Very Much Functional \\
\hline $\begin{array}{l}\text { 7. Fitness of its intended } \\
\text { use }\end{array}$ & 4.67 & $\begin{array}{l}\text { Very Much } \\
\text { Functional }\end{array}$ & 4.71 & Very Much Functional \\
\hline $\begin{array}{l}\text { 8. Minimization of its run- } \\
\text { time error }\end{array}$ & 4.46 & $\begin{array}{l}\text { Very Much } \\
\text { Functional }\end{array}$ & 4.54 & Very Much Functional \\
\hline
\end{tabular}




\begin{tabular}{|c|c|c|c|c|}
\hline 9. Detection of error & 4.42 & $\begin{array}{l}\text { Very Much } \\
\text { Functional }\end{array}$ & 4.46 & Very Much Functional \\
\hline 10. Data storage & 4.42 & $\begin{array}{l}\text { Very Much } \\
\text { Functional }\end{array}$ & 4.50 & Very Much Functional \\
\hline Mean & $\mathbf{4 . 3 4}$ & $\begin{array}{l}\text { Very Much } \\
\text { Functional }\end{array}$ & $\mathbf{4 . 4 0}$ & $\begin{array}{c}\text { Very Much } \\
\text { Functional }\end{array}$ \\
\hline
\end{tabular}

\section{Reliability}

Reliability refers to the ability of the classroom surveillance system to consistently perform its intended or required function or mission on demand and without degradation or failure. Taking a look at the responses in Table 4, IT professionals affirmed that the system is "very much reliable" with a mean of 4.30. The IT professionals were also complemented by the IT students who averred that the system was truly "very much reliable" with a mean of 4.35 . This means that the system has the ability to consistently capture and transfer images and videos. Further, it implies that the classroom surveillance system could perform the monitoring the personnel, students, and classroom facilities

Table 4 Software Quality Factor on Reliability

\begin{tabular}{|c|c|c|c|c|}
\hline \multirow[b]{2}{*}{ Descriptors } & \multicolumn{2}{|c|}{ IT Professionals } & \multicolumn{2}{|c|}{ IT Students } \\
\hline & $\begin{array}{c}\text { Average } \\
\text { Weighted } \\
\text { Value }\end{array}$ & Description & $\begin{array}{c}\text { Average } \\
\text { Weighted } \\
\text { Value }\end{array}$ & Description \\
\hline 1. Error tolerance & 3.88 & $\begin{array}{c}\text { Much } \\
\text { Reliable }\end{array}$ & 3.96 & $\begin{array}{c}\text { Much } \\
\text { Reliable }\end{array}$ \\
\hline 2. Ease in data recovery & 4.21 & $\begin{array}{c}\text { Very Much } \\
\text { Reliable }\end{array}$ & 4.21 & $\begin{array}{c}\text { Very Much } \\
\text { Reliable }\end{array}$ \\
\hline 3. Program security & 4.17 & $\begin{array}{c}\text { Much } \\
\text { Reliable }\end{array}$ & 4.25 & $\begin{array}{c}\text { Very Much } \\
\text { Reliable }\end{array}$ \\
\hline 4. Data security & 4.38 & $\begin{array}{l}\text { Very Much } \\
\text { Reliable }\end{array}$ & 4.38 & $\begin{array}{l}\text { Very Much } \\
\text { Reliable }\end{array}$ \\
\hline 5. Creation of back-up system & 4.75 & $\begin{array}{c}\text { Very Much } \\
\text { Reliable }\end{array}$ & 4.79 & $\begin{array}{c}\text { Very Much } \\
\text { Reliable }\end{array}$ \\
\hline 6. Accuracy of data capture & 4.25 & $\begin{array}{c}\text { Very Much } \\
\text { Reliable }\end{array}$ & 4.29 & $\begin{array}{c}\text { Very Much } \\
\text { Reliable }\end{array}$ \\
\hline 7. Accuracy of Results & 4.17 & $\begin{array}{c}\text { Much } \\
\text { Reliable }\end{array}$ & 4.25 & $\begin{array}{l}\text { Very Much } \\
\text { Reliable }\end{array}$ \\
\hline 8. Data storage volume & 4.38 & $\begin{array}{c}\text { Very Much } \\
\text { Reliable }\end{array}$ & 4.46 & $\begin{array}{c}\text { Very Much } \\
\text { Reliable }\end{array}$ \\
\hline 9. Understandability of output & 4.33 & $\begin{array}{c}\text { Very Much } \\
\text { Reliable }\end{array}$ & 4.38 & $\begin{array}{c}\text { Very Much } \\
\text { Reliable }\end{array}$ \\
\hline $\begin{array}{l}\text { 10. Completeness of the } \\
\text { System }\end{array}$ & 4.50 & $\begin{array}{l}\text { Very Much } \\
\text { Reliable }\end{array}$ & 4.54 & $\begin{array}{c}\text { Very Much } \\
\text { Reliable }\end{array}$ \\
\hline
\end{tabular}




\begin{tabular}{|c|c|c|c|c|}
\hline Mean & 4.30 & $\begin{array}{c}\text { Very Much } \\
\text { Reliable }\end{array}$ & 4.35 & $\begin{array}{c}\text { Very Much } \\
\text { Reliable }\end{array}$ \\
\hline
\end{tabular}

\section{Usability}

In this investigation, usability pertains to the user's total satisfaction out of using the classroom surveillance system. Looking at the responses of the respondents in Table 7, the IT professionals disclosed that the system was "very much usable" which obtained a mean of 4.35. Moreover, as to the students respondents, the system was also "very much usable" with a registered mean of 4.41. This means that the system has provided the user's total contentment in the classroom surveillance system.

Table 5 Software Quality Factor on Usability

\begin{tabular}{|c|c|c|c|c|}
\hline \multirow[b]{2}{*}{ Descriptors } & \multicolumn{2}{|c|}{ IT Professionals } & \multicolumn{2}{|c|}{ IT Students } \\
\hline & $\begin{array}{c}\text { Average } \\
\text { Weighted } \\
\text { Value }\end{array}$ & Description & $\begin{array}{c}\text { Average } \\
\text { Weighted } \\
\text { Value }\end{array}$ & Description \\
\hline 1. User friendly program & 4.38 & $\begin{array}{l}\text { Very Much } \\
\text { Usable }\end{array}$ & 4.42 & $\begin{array}{l}\text { Very Much } \\
\text { Usable }\end{array}$ \\
\hline 2. Quick driven program & 4.50 & $\begin{array}{l}\text { Very Much } \\
\text { Usable }\end{array}$ & 4.54 & $\begin{array}{l}\text { Very Much } \\
\text { Usable }\end{array}$ \\
\hline $\begin{array}{l}\text { 3. Simple manipulation } \\
\text { features }\end{array}$ & 4.58 & $\begin{array}{l}\text { Very Much } \\
\text { Usable }\end{array}$ & 4.63 & $\begin{array}{l}\text { Very Much } \\
\text { Usable }\end{array}$ \\
\hline $\begin{array}{l}\text { 4. Wrong key input errors } \\
\text { detection }\end{array}$ & 4.42 & $\begin{array}{l}\text { Very Much } \\
\text { Usable }\end{array}$ & 4.46 & $\begin{array}{l}\text { Very Much } \\
\text { Usable }\end{array}$ \\
\hline $\begin{array}{l}\text { 5. Wrong time input errors } \\
\text { detection }\end{array}$ & 4.29 & $\begin{array}{l}\text { Very Much } \\
\text { Usable }\end{array}$ & 4.38 & $\begin{array}{l}\text { Very Much } \\
\text { Usable }\end{array}$ \\
\hline 6. Data storage & 4.17 & Much Usable & 4.25 & $\begin{array}{l}\text { Very Much } \\
\text { Usable }\end{array}$ \\
\hline 7. Data retrieval & 4.13 & Much Usable & 4.17 & $\begin{array}{c}\text { Much } \\
\text { Usable }\end{array}$ \\
\hline 8. Data edit/correction & 4.25 & $\begin{array}{l}\text { Very Much } \\
\text { Usable }\end{array}$ & 4.29 & $\begin{array}{l}\text { Very Much } \\
\text { Usable }\end{array}$ \\
\hline $\begin{array}{l}\text { 9. Tolerable difficulty } \\
\text { level }\end{array}$ & 4.46 & $\begin{array}{l}\text { Very Much } \\
\text { Usable }\end{array}$ & 4.50 & $\begin{array}{l}\text { Very Much } \\
\text { Usable }\end{array}$ \\
\hline $\begin{array}{l}\text { 10. Production of data } \\
\text { output }\end{array}$ & 4.33 & $\begin{array}{l}\text { Very Much } \\
\text { Usable }\end{array}$ & 4.46 & $\begin{array}{l}\text { Very Much } \\
\text { Usable }\end{array}$ \\
\hline Mean & 4.35 & $\begin{array}{l}\text { Very Much } \\
\text { Usable }\end{array}$ & 4.41 & $\begin{array}{l}\text { Very Much } \\
\text { Usable }\end{array}$ \\
\hline
\end{tabular}




\section{Efficiency}

Efficiency, in this study, refers to what is actually produced or performed by the classroom surveillance system with what can be achieved in contrast with the traditional surveillance. . These include: Support on minimum facilities which obtained as average weighted value of 4.13 , and is described as much efficient; Support on minimum requirements which obtained an average weighted value of 4.71 and is described as very much efficient; Provision on configurable automation which obtained an average weighted value of 4.54 and is described as very much efficient; Support on business workflow process obtained an average weighted value of 4.46 described as very much efficient; Support of number of users at a time with an average weighted value of 4.50 described as very much efficient; Speed of navigation and production of outputs obtained an average weighted value of
3.96 described as much efficient; Speed of data capture and retrieval obtained an average weighted value of 4.21 described as very much efficient; Hardware utilization obtained an average weighted value of 4.25 described as very much efficient; Support on interfacing with other devices with an average weighted value of 4.38 described as very much efficient and compatibility with interfaced devices obtained an average weighted value oif 4.79 described as very much efficient. These ratings were taken from the IT students as evaluators. Evidently as reflected in Table 6, IT professionals disclosed that the system was "very much efficient" with 4.34 as the mean. The rating was strongly supported by the IT students who also rated the system as "very much efficient" with a mean of 4.39. This means that the system could produce what it is expected to produce. Moreover, the system is very much efficient in determining productivity.

Table 6 Software Quality Factor on Efficiency

\begin{tabular}{|l|c|c|c|c|}
\hline \multicolumn{1}{|c|}{ Descriptors } & \multicolumn{2}{|c|}{ IT Professionals } & \multicolumn{2}{c|}{ IT Students } \\
\cline { 2 - 5 } & $\begin{array}{c}\text { Average } \\
\text { Weighted } \\
\text { Value }\end{array}$ & Description & $\begin{array}{c}\text { Average } \\
\text { Weighted } \\
\text { Value }\end{array}$ & Description \\
\hline $\begin{array}{c}\text { 1. Support on minimum } \\
\text { facilities }\end{array}$ & 4.08 & $\begin{array}{c}\text { Much } \\
\text { Efficient }\end{array}$ & 4.13 & $\begin{array}{c}\text { Much } \\
\text { Efficient }\end{array}$ \\
\hline $\begin{array}{c}\text { 2. Support on minimum } \\
\text { requirements }\end{array}$ & 4.67 & $\begin{array}{c}\text { Very Much } \\
\text { Efficient }\end{array}$ & 4.71 & $\begin{array}{c}\text { Very Much } \\
\text { Efficient }\end{array}$ \\
\hline $\begin{array}{c}\text { 3. Provision of configurable } \\
\text { automation }\end{array}$ & 4.46 & $\begin{array}{c}\text { Very Much } \\
\text { Efficient }\end{array}$ & 4.54 & $\begin{array}{c}\text { Very Much } \\
\text { Efficient }\end{array}$ \\
\hline $\begin{array}{l}\text { 4. Support on business } \\
\text { workflow process }\end{array}$ & 4.42 & $\begin{array}{c}\text { Very Much } \\
\text { Efficient } \\
\text { Efficient }\end{array}$ & 4.46 & $\begin{array}{c}\text { Very Much } \\
\text { Efficient }\end{array}$ \\
\hline $\begin{array}{c}\text { 5. Support on number of } \\
\text { user's at a time }\end{array}$ & 3.88 & $\begin{array}{c}\text { Much } \\
\text { Efficient }\end{array}$ & 3.90 & $\begin{array}{c}\text { Very Much } \\
\text { Efficient }\end{array}$ \\
\hline $\begin{array}{l}\text { 6. Speed of navigation and } \\
\text { production of outputs }\end{array}$ & \multicolumn{2}{|c|}{$\begin{array}{c}\text { Much } \\
\text { Efficient }\end{array}$} \\
\hline
\end{tabular}




\begin{tabular}{|c|c|c|c|c|}
\hline $\begin{array}{l}\text { 7. Speed of data capture and } \\
\text { retrieval }\end{array}$ & 4.21 & $\begin{array}{l}\text { Very Much } \\
\text { Efficient }\end{array}$ & 4.21 & $\begin{array}{l}\text { Very Much } \\
\text { Efficient }\end{array}$ \\
\hline 8. Hardware utilization & 4.17 & $\begin{array}{c}\text { Much } \\
\text { Efficient }\end{array}$ & 4.25 & $\begin{array}{l}\text { Very Much } \\
\text { Efficient }\end{array}$ \\
\hline $\begin{array}{l}\text { 9. Support on interfacing with } \\
\text { other devices }\end{array}$ & 4.38 & $\begin{array}{l}\text { Very Much } \\
\text { Efficient }\end{array}$ & 4.38 & $\begin{array}{l}\text { Very Much } \\
\text { Efficient }\end{array}$ \\
\hline $\begin{array}{l}\text { 10. Compatibility with } \\
\text { interfaced devices }\end{array}$ & 4.75 & $\begin{array}{l}\text { Very Much } \\
\text { Efficient }\end{array}$ & 4.79 & $\begin{array}{l}\text { Very Much } \\
\text { Efficient }\end{array}$ \\
\hline Mean & 4.34 & $\begin{array}{l}\text { Very Much } \\
\text { Efficient }\end{array}$ & 4.39 & $\begin{array}{l}\text { Very Much } \\
\text { Efficient }\end{array}$ \\
\hline
\end{tabular}

\section{Maintainability}

Table 7 presents the maintainability status of the system. As seen in the table, IT professionals and students both rated the system as "very much maintainable" with the obtained mean of 4.38 and
4.44, respectively. This means that the system is not difficult to maintain and can simply be handled for any repair. Moreover, the system can be easily facilitated for a scheduled inspection, servicing, and restoration.

Table 7 Software Quality Factor on Maintainability

\begin{tabular}{|c|c|c|c|c|}
\hline \multirow[b]{2}{*}{ Descriptors } & \multicolumn{2}{|c|}{ IT Professionals } & \multicolumn{2}{|c|}{ IT Students } \\
\hline & $\begin{array}{c}\text { Average } \\
\text { Weighted } \\
\text { Value }\end{array}$ & Description & $\begin{array}{c}\text { Average } \\
\text { Weighted } \\
\text { Value }\end{array}$ & Description \\
\hline $\begin{array}{l}\text { 1. Modification of the } \\
\text { system software }\end{array}$ & 4.25 & $\begin{array}{l}\text { Very Much } \\
\text { Maintainable }\end{array}$ & 4.29 & $\begin{array}{l}\text { Very Much } \\
\text { Maintainable }\end{array}$ \\
\hline $\begin{array}{l}\text { 2. Change of software } \\
\text { capabilities }\end{array}$ & 4.17 & $\begin{array}{c}\text { Much } \\
\text { Maintainable }\end{array}$ & 4.25 & $\begin{array}{l}\text { Very Much } \\
\text { Maintainable }\end{array}$ \\
\hline $\begin{array}{l}\text { 3. Increase program } \\
\text { capabilities }\end{array}$ & 4.38 & $\begin{array}{l}\text { Very Much } \\
\text { Maintainable }\end{array}$ & 4.46 & $\begin{array}{l}\text { Very Much } \\
\text { Maintainable }\end{array}$ \\
\hline 4. Improving performance & 4.33 & $\begin{array}{l}\text { Very Much } \\
\text { Maintainable }\end{array}$ & 4.38 & $\begin{array}{l}\text { Very Much } \\
\text { Maintainable }\end{array}$ \\
\hline $\begin{array}{l}\text { 5. Correction of program } \\
\text { defects }\end{array}$ & 4.50 & $\begin{array}{l}\text { Very Much } \\
\text { Maintainable }\end{array}$ & 4.54 & $\begin{array}{l}\text { Very Much } \\
\text { Maintainable }\end{array}$ \\
\hline $\begin{array}{l}\text { 6. Accessibility for } \\
\text { maintenance }\end{array}$ & 4.38 & $\begin{array}{l}\text { Very Much } \\
\text { Maintainable }\end{array}$ & 4.42 & $\begin{array}{l}\text { Very Much } \\
\text { Maintainable }\end{array}$ \\
\hline $\begin{array}{l}\text { 7. Configuration of system } \\
\text { operation }\end{array}$ & 4.50 & $\begin{array}{l}\text { Very Much } \\
\text { Maintainable }\end{array}$ & 4.54 & $\begin{array}{l}\text { Very Much } \\
\text { Maintainable }\end{array}$ \\
\hline $\begin{array}{l}\text { 8. Flexibility for system } \\
\text { modification }\end{array}$ & 4.58 & $\begin{array}{l}\text { Very Much } \\
\text { Maintainable }\end{array}$ & 4.63 & $\begin{array}{l}\text { Very Much } \\
\text { Maintainable }\end{array}$ \\
\hline $\begin{array}{l}\text { 9. Compliance of concurrent } \\
\text { system requirements }\end{array}$ & 4.42 & $\begin{array}{l}\text { Very Much } \\
\text { Maintainable }\end{array}$ & 4.46 & $\begin{array}{c}\text { Very Much } \\
\text { Maintainable }\end{array}$ \\
\hline
\end{tabular}




\begin{tabular}{|c|c|c|c|c|}
\hline $\begin{array}{c}\text { 10. Advance feature for } \\
\text { recent technology }\end{array}$ & 4.29 & $\begin{array}{c}\text { Very Much } \\
\text { Maintainable }\end{array}$ & 4.38 & $\begin{array}{c}\text { Very Much } \\
\text { Maintainable }\end{array}$ \\
\hline Mean & $\mathbf{4 . 3 8}$ & $\begin{array}{c}\text { Very Much } \\
\text { Maintainabl } \\
\mathbf{e}\end{array}$ & $\mathbf{4 . 4 4}$ & $\begin{array}{c}\text { Very Much } \\
\text { Maintainabl } \\
\mathbf{e}\end{array}$ \\
\hline
\end{tabular}

\section{Accuracy}

Accuracy refers to the ability of the classroom surveillance system to match the actual expected performance of the system being measured. Taking a look at the responses of the IT professionals as shown in Table 10, respondents rated the system as "very much accurate" with the mean of 4.34 . This was complemented by the IT students who rated that the system as "very much accurate" with a mean of 4.40. This means that the system captures image which give correct information. Further, this implies that the classroom surveillance system is trusted to provide accurate observation when the system is operational.

Table 8 Software Quality Factor on Maintainability

\begin{tabular}{|c|c|c|c|c|}
\hline \multirow[b]{2}{*}{ Descriptors } & \multicolumn{2}{|c|}{ IT Professionals } & \multicolumn{2}{|c|}{ IT Students } \\
\hline & $\begin{array}{c}\text { Average } \\
\text { Weighted } \\
\text { Value }\end{array}$ & Description & $\begin{array}{c}\text { Average } \\
\text { Weighted } \\
\text { Value }\end{array}$ & Description \\
\hline 1. Modification of the system & 4.17 & $\begin{array}{c}\text { Much } \\
\text { Accurate }\end{array}$ & 4.25 & $\begin{array}{l}\text { Very Much } \\
\text { Accurate }\end{array}$ \\
\hline $\begin{array}{l}\text { 2. Adaptability to other } \\
\text { environment }\end{array}$ & 4.13 & $\begin{array}{c}\text { Much } \\
\text { Accurate }\end{array}$ & 4.17 & $\begin{array}{c}\text { Much } \\
\text { Accurate }\end{array}$ \\
\hline $\begin{array}{l}\text { 3. Adaptability to other } \\
\text { applications }\end{array}$ & 4.25 & $\begin{array}{l}\text { Very Much } \\
\text { Accurate }\end{array}$ & 4.29 & $\begin{array}{l}\text { Very Much } \\
\text { Accurate }\end{array}$ \\
\hline 4. Flexibility to other settings & 4.46 & $\begin{array}{l}\text { Very Much } \\
\text { Accurate }\end{array}$ & 4.50 & $\begin{array}{l}\text { Very Much } \\
\text { Accurate }\end{array}$ \\
\hline $\begin{array}{l}\text { 5. Support in any form of } \\
\text { network communication }\end{array}$ & 4.33 & $\begin{array}{l}\text { Very Much } \\
\text { Accurate }\end{array}$ & 4.46 & $\begin{array}{l}\text { Very Much } \\
\text { Accurate }\end{array}$ \\
\hline $\begin{array}{l}\text { 6. Adaptability to new version } \\
\text { of system requirements }\end{array}$ & 4.08 & $\begin{array}{c}\text { Much } \\
\text { Accurate }\end{array}$ & 4.13 & $\begin{array}{c}\text { Much } \\
\text { Accurate }\end{array}$ \\
\hline $\begin{array}{l}\text { 7. System supports on } \\
\text { maximum hardware } \\
\text { requirements }\end{array}$ & 4.67 & $\begin{array}{l}\text { Very Much } \\
\text { Accurate }\end{array}$ & 4.71 & $\begin{array}{l}\text { Very Much } \\
\text { Accurate }\end{array}$ \\
\hline 8. User capability/capacity & 4.46 & $\begin{array}{l}\text { Very Much } \\
\text { Accurate }\end{array}$ & 4.54 & $\begin{array}{l}\text { Very Much } \\
\text { Accurate }\end{array}$ \\
\hline 9. Its intended application & 4.42 & $\begin{array}{l}\text { Very Much } \\
\text { Accurate }\end{array}$ & 4.46 & $\begin{array}{l}\text { Very Much } \\
\text { Accurate }\end{array}$ \\
\hline 10. Its intended design & 4.42 & $\begin{array}{l}\text { Very Much } \\
\text { Accurate }\end{array}$ & 4.50 & $\begin{array}{l}\text { Very Much } \\
\text { Accurate }\end{array}$ \\
\hline
\end{tabular}




\begin{tabular}{|c|c|c|c|c|}
\hline Mean & 4.34 & $\begin{array}{c}\text { Very Much } \\
\text { Accurate }\end{array}$ & 4.40 & $\begin{array}{c}\text { Very Much } \\
\text { Accurate }\end{array}$ \\
\hline
\end{tabular}

Problem No. 5. What technological features could be developed for a new classroom surveillance system?

Table 11 presents the technological features of the Classroom Surveillance System (CSS) for Jose
Rizal Memorial State University, Dipolog Campus. A closer look at the table shows that the CSC has twenty-eight (28) technological features. These features are significantly combined by the proponent to come up with a hybrid classroom surveillance system.

Table 9 Technological Features of the Classroom Surveillance System

\begin{tabular}{|c|c|}
\hline Technological Features & $\begin{array}{c}\text { Classroom } \\
\text { Surveillance System }\end{array}$ \\
\hline Motion Detection & $\checkmark$ \\
\hline * Motion Detection Alarm System & $\checkmark$ \\
\hline Mobile Phones Warning Message Alarm & $\checkmark$ \\
\hline Night Vision Capabilities & $\checkmark$ \\
\hline $\begin{array}{l}\text { Uses SMS to Tract Text Messages to the Registered } \\
\text { Users }\end{array}$ & $\checkmark$ \\
\hline $\begin{array}{l}\text { Supports multiple number of IP cameras connected to the } \\
\text { computer }\end{array}$ & $\checkmark$ \\
\hline Sends snapshot through Email & $\checkmark$ \\
\hline Schedules recording & $\checkmark$ \\
\hline Live video scenes through the internet & $\checkmark$ \\
\hline $\begin{array}{l}\text { Follows movement of the moving object (remote pan/tilt } \\
\text { rotate) }\end{array}$ & $\checkmark$ \\
\hline Supports up to 4 users online simultaneous & $\checkmark$ \\
\hline Multi-level users management and password definition & $\checkmark$ \\
\hline Frame ratio or bandwidth can be adjusted & $\checkmark$ \\
\hline No longer requires Digital Video Recorder (DVR)Device & $\checkmark$ \\
\hline Executable Client Application & $\checkmark$ \\
\hline \multicolumn{2}{|l|}{ Continuation of Table 10} \\
\hline Browser Enabled & $\checkmark$ \\
\hline * Adjust Resolution & $\checkmark$ \\
\hline Mobile Browser & $\checkmark$ \\
\hline Record Stream & $\checkmark$ \\
\hline View and Select Camera & $\checkmark$ \\
\hline
\end{tabular}




\begin{tabular}{|l|c|}
\hline Play Recorded Video & $\checkmark$ \\
\hline - Camera Troubleshooting & $\checkmark$ \\
\hline Centralized Configuration & $\checkmark$ \\
\hline - Centralized Storage for Video Streams & $\checkmark$ \\
\hline - Wuto save with date and time & $\checkmark$ \\
\hline
\end{tabular}

Figure 3 shows the hybrid software features of the newly developed Classroom Surveillance System (CSS). As defined by Orong (2015), hybrid software refers to the existing system developed and used by an organization that helps people in the organization in their daily activities as to serving their clients and providing quality and excellent services to their customers. The developed Classroom Surveillance System for Jose Rizal Memorial State University is a hybrid system which combined the features of the existing classroom surveillance systems, namely: the Automated Surveillance System (ASS), Physical Security Solutions (PSS), and Campus Emergency Warning System (CEWS).

It can be seen in the Figure 3 that fourteen (14) features were drawn from the Automated Surveillance System (ASS) of Lagonero (2011), nine (9) features were derived from the Physical Security Solutions (PSS), and eight (8) features were extracted from the Campus Emergency Warning System (CEWS). The figure shows further that the proponent added fourteen (14) more features to the newly developed hybrid CSS. The fourteen (14) various significant features that users expect to experience, namely: executable client application, browser enabled, adjust resolution, mobile browser, record stream, view and select camera, play recorded video, camera troubleshooting, camera status (1054 $\mathrm{MB}$ (megabyte) is equal to 1 minute recording of a single image captured by the camera. Megabyte is a unit of the storage capacity of a disk. Computing the size of storage consumed in 1 day, the computation would be as follows: $1054 \mathrm{MB}$ times $60 \mathrm{~min}(1 \mathrm{hr})=$ $63,240 \mathrm{MB}$ (consumed storage in $1 \mathrm{hr}$ ) $63,240 \mathrm{MB}$ times $24 \mathrm{hr}=1,517,760 \mathrm{~GB}$ (consumed storage in 1 day) $1,517,760 \mathrm{~GB} \times$ 30days $=45,532,800 \mathrm{~GB}$ (consumed storage in 1 month) A single hard drive like 500Gigabyte, can be totally consumed in 10 months), centralized configuration, centralized storage for video streams, centralized IP configuration, auto save with date and time, and wireless access. These fourteen (14) features were fused to the Automated Surveillance System to the Physical Security Solution and Campus Emergency Warning System. Simply stated, the newly developed Classroom Surveillance System for Jose Rizal Memorial State University, Dipolog Campus, is a system which contained more significant features as compared to the systems, namely: Automated Surveillance System (ASS), Physical Security Solutions (PSS), and Campus Emergency Warning System (CEWS). 

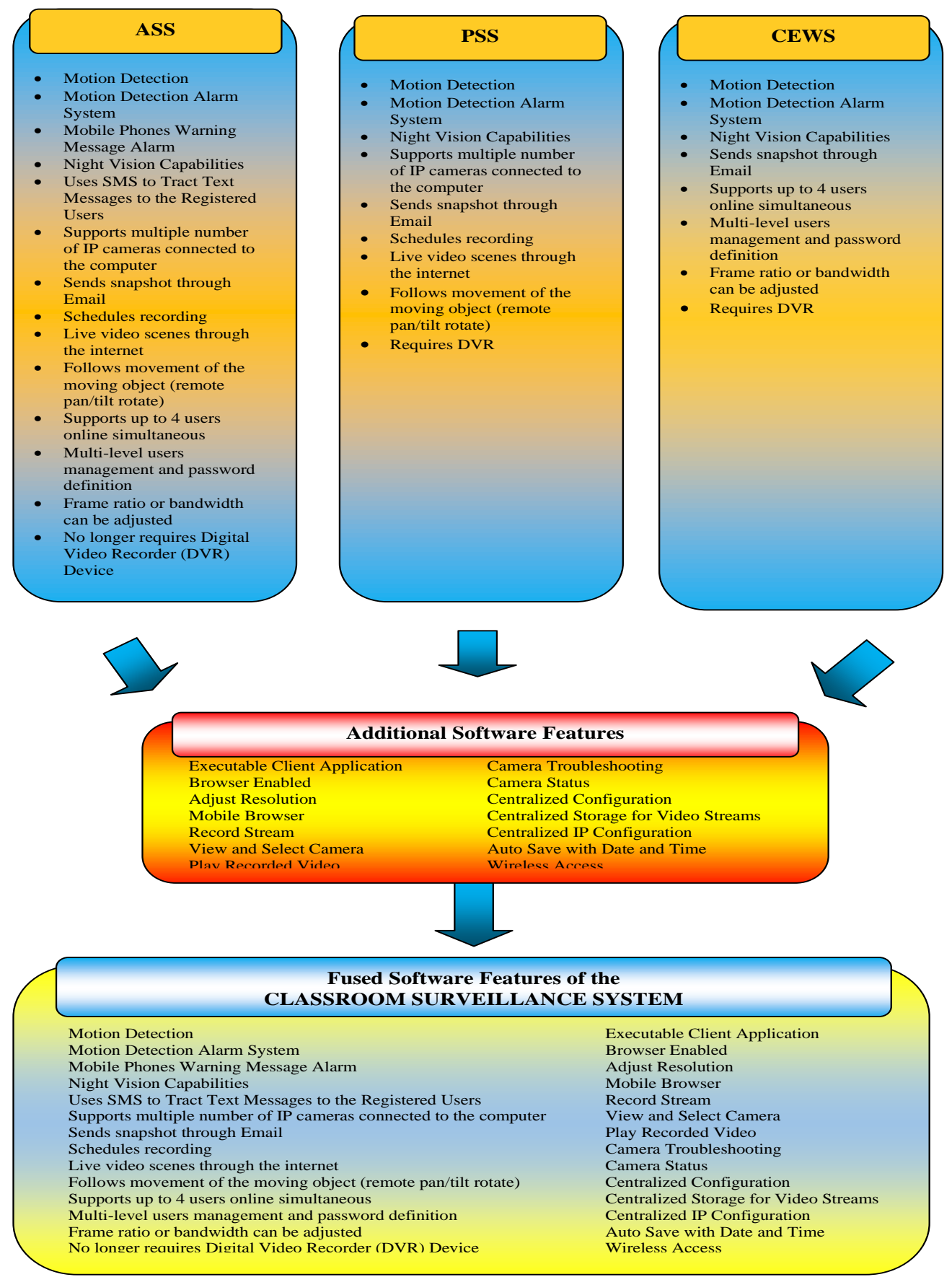

Figure 3 Hybrid Software Features of the Classroom Surveillance System

\section{Conclusion}

Based on the features of the system, the Classroom Surveillance System could be adopted as an excellent system to navigate classroom surveillance of teaching and non-teaching personnel, classroom facilities, and students of Jose Rizal Memorial State University, Dipolog Campus. The system further is an excellent surveillance system which highlights the combined features of the Automated Surveillance System, CISCO Physical Security Solutions, and Campus Emergency Warning System (CEWS). Moreover, the system is excellent for implementation to increase the university's safety and security measures.

\section{Recommendations}


The following recommendations are given: (1) Deans and other monitoring personnel of Jose Rizal Memorial State University, Dipolog Campus should look into the classroom surveillance/monitoring scheme that provides excellent surveillance result for their teaching and non-teaching personnel, classroom facilities, and students. A shift from utilizing the traditional surveillance system into a technologically oriented surveillance system is best suggested; (2) The President, Vice Presidents, and Deans of Jose Rizal Memorial State University System should adopt the Classroom Surveillance System to provide excellent surveillance/monitoring scheme of teaching personnel, non-teaching personnel, classroom facilities, and students of the University; (3) further studies should be conducted to ascertain the effectiveness of the system using its actual utilization to wider schools.

\section{References}

[1] Al-Qawasmi, A. R., \& Tlili, I. (2018). Energy efficiency and economic impact investigations for air-conditioners using wireless sensing and actuator networks. Energy Reports, 4, 478-485.

[2] Birnhack, M., \& Perry-Hazan, L. (2020). School Surveillance in Context: High School Students' Perspectives on CCTV, Privacy, and Security. Youth \& Society, 52(7), 13121330. IEEE Access, 8, 136434-136448.

[3] Ceccato, V., Wiebe, D. J., Vrotsou, K., Nyberg, U., \& Grundberg, A. (2021). The situational conditions of suicide in transit environments: An analysis using CCTV footage. Journal of Transport \& Health, 20, 100976.

[4] Cho, J. T., \& Park, J. (2017). Exploring the effects of CCTV upon fear of crime: A multilevel approach in Seoul. International Journal of Law, Crime and Justice, 49, 35-45.

[5] Cho, V., Mansfield, K. C., \& Claughton, J. (2020). The past and future technology in classroom management and school discipline: A systematic review. Teaching and Teacher Education, 90, 103037.

[6] Effah, J., Amankwah-Sarfo, F., \& Boateng, R. (2020). Affordances and constraints processes of smart service systems: Insights from the case of seaport security in Ghana. International Journal of Information Management, 102204.

[7] Fisher, B. W., Gardella, J. H., \& TannerSmith, E. E. (2019). Social control in schools: The relationships between school security measures and informal social control mechanisms. Journal of school violence, 18(3), 347-361.

[8] Hodgetts, H. M., Vachon, F., Chamberland, C., \& Tremblay, S. (2017). See no evil: Cognitive challenges of security surveillance and monitoring. Journal of applied research in memory and cognition, 6(3), 230-243.

[9] Jansen, K., Schäfer, M., Lenders, V., Pöpper, C., \& Schmitt, J. (2017, April). Localization of Spoofing Devices using a Large-scale Air Traffic Surveillance System. In Proceedings of the 2017 ACM on Asia conference on computer and communications security (pp. 914-916).

[10] Kennedy, M. (2017). Enhancing school security: Guidance for ensuring the safest possible school environments. American School \& University, 90(2), 14-17.

[11] Kwet, M., \& Prinsloo, P. (2020). The 'smart'classroom: a new frontier in the age of the smart university. Teaching in Higher Education, 25(4), 510-526.

[12] Lukas, S., Mitra, A. R., Desanti, R. I., \& Krisnadi, D. (2016, October). Student attendance system in classroom using face recognition technique. In 2016 International Conference on Information and Communication Technology Convergence (ICTC) (pp. 1032-1035). IEEE.

[13] Perry-Hazan, L., \& Birnhack, M. (2019). Caught on camera: Teachers' surveillance in 
schools. Teaching and teacher education, 78, 193-204.

[14] Robin, L., Peterson, B. E., \& Lawrence, D. S. (2020). How do close-circuit television cameras impact crimes and clearances? An evaluation of the Milwaukee police department's public surveillance system. Police Practice and Research, 1-20.

[15] Shepelev, V., Aliukov, S., Nikolskaya, K., Das, A., \& Slobodin, I. (2020). The use of multi-sensor video surveillance system to assess the capacity of the road network. Transport and Telecommunication Journal, 21(1), 15-31.

[16] Socha, R., \& Kogut, B. (2020). Urban Video Surveillance as a Tool to Improve Security in Public Spaces. Sustainability, 12(15), 6210.

[17] Stainer, M. J., Raj, P. V., Aitken, B. M., Bandarian-Balooch, S., \& Boschen, M. J. (2021). Decision-making in single and multiple-screen CCTV surveillance. Applied Ergonomics, 93, 103383.

[18] Surantha, N., \& Wicaksono, W. R. (2018). Design of smart home security system using object recognition and PIR sensor. Procedia computer science, 135, 465-472.

[19] Underwood, J. M., Brener, N., Thornton, J., Harris, W. A., Bryan, L. N., Shanklin, S. L., ... \& Dittus, P. (2020). Overview and methods for the Youth Risk Behavior Surveillance System-United States, 2019. MMWR supplements, 69(1), 1.

[20] Wagner, W. P. (2017). Trends in expert system development: A longitudinal content analysis of over thirty years of expert system case studies. Expert systems with applications, 76, 85-96.

[21] Wang, Z. (2020). Recognition and Analysis of Behavior Features of School-Age Children Based on Video Image Processing. Traitement du Signal, 37(4).

[22] Zhou, Z., Yu, H., \& Shi, H. (2020). Optimization of Wireless Video Surveillance
System for Smart Campus Based on Internet of Things.

[23] Zhou, Z., Yu, H., \& Shi, H. (2020). Optimization of Wireless Video Surveillance System for Smart Campus Based on Internet of Things. IEEE Access, 8, 136434-136448. 